\title{
The Formation of Professional Identity in Nursing
}

\section{Hemşirelikte Profesyonel Kimlik Oluşumu}

\author{
Yasemin GÜNER ${ }^{a}$, Ebru TURHAL ${ }^{\mathrm{b}}$, Melek ÜÇÜNCÜOĞLU ${ }^{a}$, Bilge TUNCEL ${ }^{a}$, \\ Selçuk AKTURAN ${ }^{a}$, Şükrü KELEŞ ${ }^{c}$
}

\begin{abstract}
Professional identity is formed when the responsibilities of being a nurse are understood, internalized, and attitudes, beliefs, and standards that support the development of identity are improved. The formation of professional identity in nursing is a dynamic process that starts during nursing education and continues to develop throughout each nurse's professional career. Education, individual expectations, and experiences are significant factors in the formation of professional identity nursing. Professional identity contributes to nurses in reflecting their competencies in line with their professional practices and thus positively affects their social interactions with patients, their relatives, and colleagues.

The formation processes of the professional identities of nurses are essential for the development of the nursing profession. This review presents information on the professional identity formation process in nursing, the associated factors, and domestic and international curriculum activities in this field.
\end{abstract}

Keywords: Nurses; professional competence; professional ethics; professionalism

$-$

Özet: Profesyonel kimlik, hemşire olmanın sorumlulukların anlamak, içselleştirmek ve kimliğin gelişimini destekleyen tutum, inanç ve standartların geliştirilmesi durumunda ortaya çıkar. Hemşirelikte profesyonel kimliğin oluşumu, hemşirelik eğitimi sırasında başlayan ve her hemşirenin mesleki kariyeri boyunca gelişmeye devam eden dinamik bir süreçtir. Hemşirelerde profesyonel kimliğin oluşunda eğitim, bireysel beklentiler ve deneyimler önemli faktörlerdir. Profesyonel kimlik gelişimi hemşirelerin yetkinliklerini mesleki uygulamalarna uygun bir şekilde yansıtmasını destekler, dolaysıyla hastalara, hasta yakınlarına ve birlikte çalıştıkları diğer sağlık çalışanlar ile gelişen mesleki veya sosyal etkileşimlerini olumlu yönde etkiler.

Hemşirelerin profesyonel kimliklerinin oluşum süreçleri, hemşirelik mesleğinin gelişimi için çok önemlidir. Bu derlemede hemşirelikte profesyonel kimlik gelişim süreci, süreci etkileyen faktörler, bu alanda yapılan yurtiçi ve yurtdışı müfredat faaliyetlerine, ilişkin bilgiler sunulmaktadır.

Anabtar kelimeler: Hemşireler; mesleki yeterlik; mesleki etikler; profesyonellik

\section{INTRODUCTION}

In today's world, one of the most significant issues of contemporary societies is professionalism. Professionalism is the acquisition of an individual's professional identity and a sense of knowledge and skill (1). Professional identity, on the other hand, is the integration with the profession, the awareness and adoption of certain

\footnotetext{
${ }^{a}$ Dr. Öğr. Üyesi, Karadeniz Teknik Üniversitesi Tip Fakültesi, Tıp Eğitimi AD, Trabzon $₫$ selcukakturan@gmail.com

${ }^{a}$ Uzm. Hemșire, Karadeniz Teknik Üniversitesi Tıp Fakültesi, Tıp Eğitimi AD, Trabzon

${ }^{a}$ Dr. Öğr. Üyesi, Karadeniz Teknik Üniversitesi Tip Fakültesi, Tip Eğitimi AD, Trabzon

${ }^{a}$ Öğr. Gör., Karadeniz Teknik Üniversitesi Tıp Fakültesi, Tıp Eğitimi AD, Trabzon

Öğr. Gör., Karadeniz Teknik Üniversitesi, İyi Hekimlik Uygulamaları ve Tıbbi Simülasyon Merkezi.

c Dr. Öğr. Üyesi, Karadeniz Teknik Üniversitesi Tip Fakültesi, Tip Tarihi ve Etik AD

Gönderim Tarihi: 08.05.2021 • Kabul Tarihi: 17.06.2021
} 
astandards and characteristics of the profession, and their reflection on professional practices. Professional identity shapes the individual's position in society and his/her interaction with society (2). Relevant literature reports that when nurses' perceptions of professional values are high, the quality of the service they provide to patients improves too $(3,4)$. For this reason, the professional identities of the members of the profession must be strong to provide quality service to society (5).

Throughout history, significant efforts have been made to make nursing a professional profession, but in this process, issues such as the lack of standard in education, the inadequacy of professional organization, the absence of specialization, and the classification of nurses as allied health personnel have been encountered $(6,7)$. The development of the nursing discipline is directly related to the healthy structuring of the professional identity development processes of those providing service in this field $(8,9)$.

In the literature, there is an increasing amount of published research on the concept of professionalism in the nursing discipline, but few studies have been conducted on the formation of professional identity and nursing education programs $(1,5,9,10)$. This review aims to determine the current state of nursing education programs in Turkey and their impact on nursing identity. It presents information on the professional identity formation process in nursing, associating factors, and domestic and international curriculum activities in this field (11). This review presents information on the professional identity formation process in nursing, associating factors, and domestic and international curriculum activities in this field.

\section{PROFESSIONAL IDENTITY FORMATION PROCESS}

Professional identity refers to a holistic definition that includes values and attitudes that make being a nurse and acting as a nurse meaningful (11). In other words, professional identity can be defined as "the integration of nurses' basic personal self-concepts with the professional qualifications they adopt" (9). The formation process of professional identity, which is also critical for the nursing discipline, is a continuous phenomenon through undergraduate education, post-graduate training, professional practices, and social interactions $(2,9,10)$. As one of the pioneers of the psycho-social development theory, Ericson argued that the identity formation process begins with adolescence and continues in adulthood, and as the individual matures, s/he will gain new competencies and thus undertake new responsibilities. Ericson also explained identity as the combination of statuses such as group identity, cultural identity, and professional identity that an individual should gain $(12,13)$.

The professional identity development of nurses has been reported to positively affect nursing practices, quality of care, patient satisfaction, and teamwork $(2,5,14)$. Therefore, it is thought that developing training programs that support professional identity development before and after graduation are of great importance for the development of professional identities of nurses.

The professional identity formation process contributes to better healthcare provision and public health through developing nursing as a profession. How professional values are acquired during nursing practices can be explained by the interaction of many factors like corporate culture, expectations, experiences, clinical environment, and social relations. The interactions of these factors that shape professional identity formation are explained with the concept of socialization.

\section{THE ROLE OF SOCIALIZATION IN THE FORMATION OF PROFESSIONAL IDENTITY}

Professional socialization is the learning of the attitudes, behaviors, and values required to gain a professional role as a result of the interactions that develop within the social and learning environment (15). This process starts 
with the education process of the individual and continuous after graduation. The professional socialization process positively affects professional identity development $(10,16)$.

The development of professional socialization has been classified by researchers in different ways $(14,17,18)$. Sabancioğulları and Doğan (2012) categorized the socialization process as primary and secondary socialization. Primary socialization takes place through the implementation processes of the structured curriculum, which is also called the formal education of nursing. Secondary socialization, on the other hand, develops in the nurse's working environment after graduation (9). In the socialization process, professional identity is formed with the acquisition of professional knowledge, skills, values, and attitudes through social interaction with experienced nurses, academicians, physicians, patients, other staff, and peers working in the field (19). Novice nurses observe, imitate, and apply their role models. In other words, they gain effective knowledge, attitude, and competence by reflecting on their experiences through guided thinking. Besides, nurses subconsciously learn the unwritten rules and culture of the profession in this process. In this case, nurses internalize their professional identities by reflection and develop an appropriate professional identity $(9,19)$.

Gray and Smith (1999) suggested that two key factors of the positive effect of socialization in the process of professional identity formation are learning environment (learning climate) and clinical educators (role models), and when these two factors are positive, they facilitate students' learning and contribute to the development of their professional identities.

In the primary and secondary socialization process, the development process of nurses' professional identity is shaped by the integration of three components (Figure 1).

\section{Figure 1.}

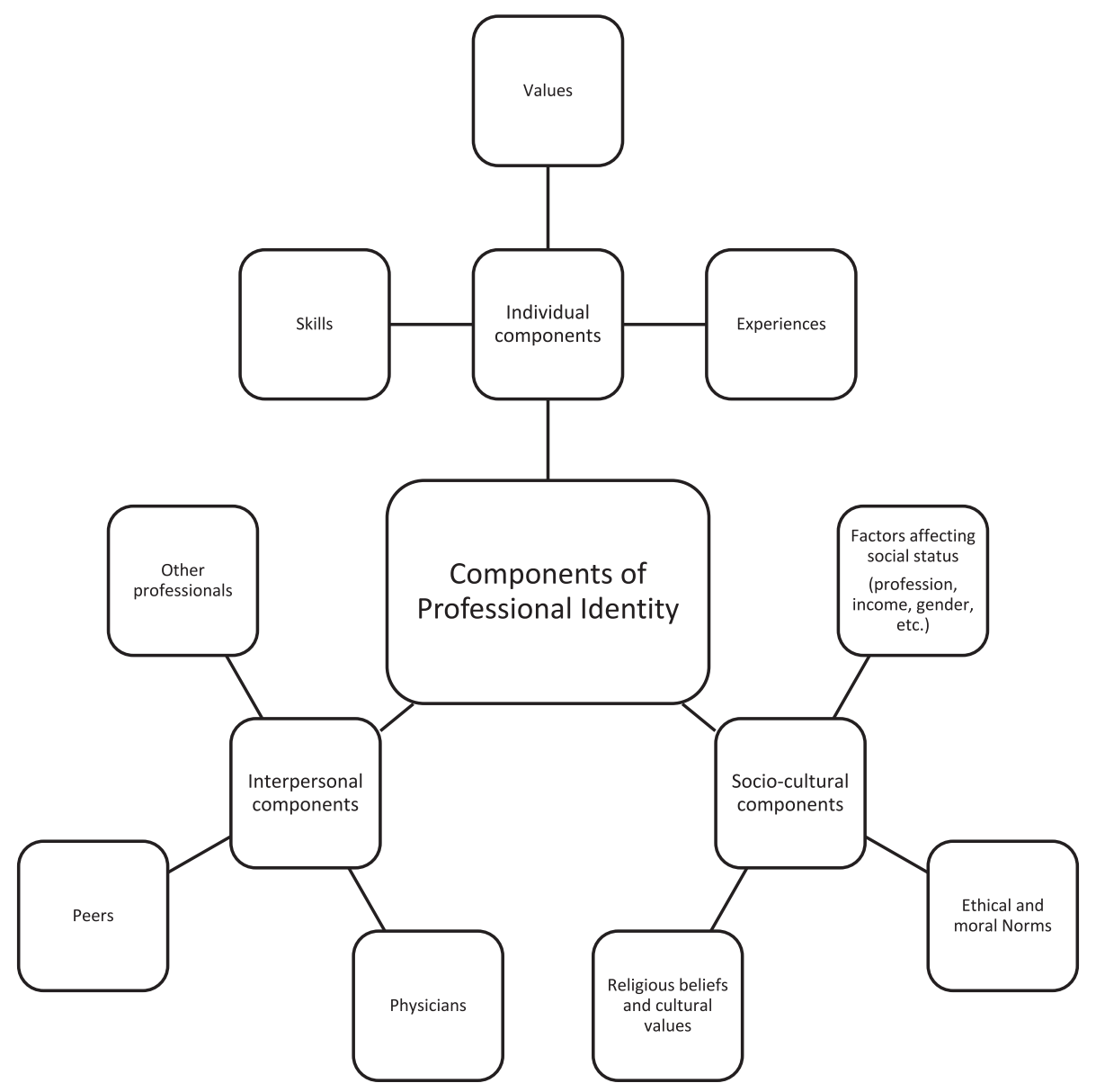


Individual components: It includes internalizing knowledge, skills, attitudes, values, and ethical standards related to nursing and making them a part of behaviors. Individual components are influenced by factors like gender, age, race, religion, nationality, culture, personality traits, socioeconomic status, marital status, personal experiences, and motivation $(9,20)$.

Interpersonal components: Interpersonal components develop as a result of nurses' interactions with academics, physicians, patients, other professionals, peers, family, and friends. The interpersonal components of professional identity positively affect nurses' awareness of their role and responsibilities, cooperation in teamwork, and effective communication $(9,20)$.

Socio-cultural components: Many social-cultural factors such as the meaning of nursing shaped in the society it serves throughout history, social status (socioeconomic status, level of organizing), religious and cultural beliefs-acceptances (the status of women in society, patriarchal structure) play an essential role in the development of professional identity (21). In other words, the social and historical dimension of nursing refers to the effect of historical events on the formation of nurses 'identity and the way how nurses' identity is perceived by the society (9).

\section{ASSOCIATING FACTORS IN THE FORMATION OF PROFESSIONAL IDENTITY IN NURSING}

Nursing profession, which has a remarkable place in the health system constantly improves and renews itself with social, cultural, and technological changes from the past to present ${ }^{1}$. In this process of change and improvement, although educational activities that contribute to the formation of professional identity in nursing have improved every day, they have not reached the desired standards and levels today (5).

The level of professionalism in nursing is positively affected by educational status, experience, membership in specialist associations, participation in scientific activities, and following relevant publications $(5,22,23)$. On the other hand, issues such as the lack of job descriptions of nurses, the inadequacy of professional organization, the deficient or wrong perceptions of the society towards nursing services, the insufficient number of nurses, the inequality in the distribution of wages in the health system, the inability to apply professional specialization in the field, the differences and inadequacies in the education system are reported to negatively affect the professional identity development of nurses (5, 23-28). A good definition of the associating factors in the professional identity development of nurses today will contribute to the structuring of undergraduate and postgraduate education programs in nursing education.

\section{PROFESSIONAL IDENTITY FORMATION IN THE CURRICULUM FOR NURSING EDUCATION}

The nursing profession is an indispensable part of the health care system to protect, develop, and improve the health of the individual, family, and society. Nursing services should be provided in line with the skills and professional attitudes developed within the framework of the standards set by the "Nursing National Core Education Program" for the health of the community (29). To provide care at professional standards, members of the profession should be supported to gain professional identity. It has been stated that the development of professional identity in nursing supports nursing care (15). Similarly, national studies also emphasize the importance of nursing education for professional identity development $(1,9)$.

Nursing education in our country is classified as undergraduate, postgraduate, and certificate programs after graduation. Undergraduate education lasts four years and includes theoretical and clinical education. Within the theoretical education, courses specific to basic sciences, social sciences, and nursing are presented. After graduation, there are postgraduate or doctorate programs in certain fields specific to nursing programs with 
or without a thesis (30-32). However, it is noteworthy that the current education programs in our country that support professional identity in nursing are insufficient. Programs that support professional identity in nursing are offered as elective courses in a limited number of universities (Dokuz Eylül University, İzmir Katip Çelebi University, Aydın Adnan Menderes University, Cumhuriyet University) (33-36). Other universities do not have educational activities to develop professionalism in nursing.

Özlük and Sur (2017) emphasized that there should be higher education programs for undergraduate education and professional identity development to professionalize the professions. In our country, nurses from different education levels (high school, associate degree, undergraduate, postgraduate) are employed in the same working environment, which negatively affects the formation of professional identity in nurses (6).

Today, different nursing programs are available in different countries in the world $(37,38)$. Countries such as the United States of America (USA), Canada, New Zealand, and Australia, where the nursing profession is more developed, have more structured education curricula than other countries. For example, in the USA, nursing education is classified as licensed practical nursing (LPN) certificate nursing, associate degree nursing (ADN), Bachelor of Science Nursing (BSN), Master of Science in Nursing (M.Sc.), and a doctorate in nursing (Ph.D.). Within this classification, each training program is constructed to be related to each other. A nurse completing any of these programs works in a unit suitable for her education level and field of expertise. By following these steps, nurses have the opportunity to increase their education level, make an academic career, and specialize in their fields(39). The literature cites that the professional identity formation of the students who completed the above-mentioned education programs developed positively $(37,38,40)$. Students with high professional identity values are reported to experience less role confusion and practice theoretical education more easily $(41,42)$. It has been reported that as the level of education increases, the professional identity of nurses improves (38).

For the formation of professional identity in the nursing discipline, it is thought that there should be postgraduate programs as well as undergraduate ones $(10,28)$. In our country, there are certificate programs in various fields such as diabetes nursing education, intensive care nursing, and emergency care nursing (43). However, there are few training programs to develop professional identity Sabancioğulları and Doğan (2015) developed a program including 10 sessions that develop professional identity after graduation in nursing based on Strasen's "professional self-image" model. Among the main topics in this program are the perception of the nursing profession, personal self-image, professional image, communication, professional contributions to the profession, and professional satisfaction. Theoretical lessons are delivered using teaching methods such as reflection, discussion, and homework. After this training, the professional self-concept of nurses was found to improve, and their burnout levels decreased (44).

\section{RECOMMENDATIONS AND CONCLUSION}

The formation process of professional identity is a continuous phenomenon through undergraduate education, post-graduate training, professional practices, and social interactions in nursing. The professional identity development of nurses is reported to affect nursing practices, quality of care, patient satisfaction, and teamwork. Socialization is another key concept in nursing that includes the learning of the attitudes, behaviors, and values required to gain a professional identity as a result of the interactions. Socialization develops within the social and learning environment. Therefore, it is pivotal to put all stakeholders into developing wellstructured training programs that support professional identity development before and after graduation. Nursing educators should also keep in mind educational activities that provide social interactions within the curriculum. 
In conclusion, it is noteworthy that there is a limited number of resources on professional identity development for the nursing profession in our country. Inadequacies in the undergraduate education curriculum prevent nursing students from comprehending professionalism comprehensively. Therefore, it can be said that professional identity development in the nursing profession cannot be achieved at the desired level.

It is understood that in our country, how nurses perceive their profession and have information about prominent values in the profession is an important issue. Planning qualitative and quantitative research in line with this subject can contribute to the development and structuring of the nursing education curriculum.

\section{REFERENCES}

1. Göriş S, Kılıç Z, Ceyhan Ö. Şentürk A. Professional values of nurses and affecting factors. J Psy Nurs. 2014;5(3):137142. Doi: $10.5505 /$ phd.2014.74046.

2. Johnson M, Cowin LS, Wilson I, Young H. Professional Identity and Nursing: Contemporary Theoretical Developments and Future Research Challenges. INR. 2012;59(4):562-569. https://doi.org/10.1111/j.14667657.2012.01013.x.

3. Çelik Bekleviç A. The effect of professional values of nurses working in surgical clinics on caring behavior: the case of Zonguldak (Master's thesis, Zonguldak Bülent Ecevit University, Institute of Health Sciences, Department of Nursing, Surgical Diseases Nursing Master's Program).2019. https://hdl.handle.net/20.500.12628/9361.

4. Geyer NM, Coetzee SK, Ellis SM, Uys LR. Relationship of nurses' intrapersonal characteristics with work performance and caring behaviors: A cross】sectional study. Nurs Health Sci. 2018;20(3):370-379. https://doi. org/10.1111/nhs.12416.

5. Ertürk C, Özmen D. Determining the variables that predict nurses' professional attitudes. DEUHEFED. 2018; 11(3):191-199.

6. Özlük B, Sur H. Assessment scope of the professionalization of nursing in turkey and the european union harmonization process: a qualitative study. JHNM. 2017;4(3):98-106. doi:10.5222/SHYD.2017.098.

7. Sağır R. Medical bureaucracies and the impact of social perception in the professionalization process of nursing profession (Master's thesis, Maltepe University, Institute of Social Sciences). 2020.

8. Strasen L. Gender Socialization and The Image of Professional Nursing. The Image of Professional Nursing; Strategies for Action. 1nd Ed. Philadelphia: J.B.Lippincott Company. 1992. p.1-63.

9. Sabancıoğulları S, Doğan S. Professional identity development and nursing. Anatolian Journal of Nursing and Health Sciences. 2012;15(4):275-282.

10. Altıok Öner H. Socialization process and professional identity development in nursing education. Adnan Menderes University Faculty of Education Journal of Educational Sciences. 2016;7(2), 55-62.

11. Vaismoradi M, Salsali M, Ahmadi F. Perspectives of Iranian male nursing students regarding the role of nursing education in developing a professional identity: a content analysis study. Jpn J Nurs Sci. 2011;8(2):174-183. https://doi.org/10.1111/j.1742-7924.2010.00172.x.

12. Atak H. Identity development and identity formation: a theoretical evaluation. Current Approaches in Psychiatry. 2011;3(1):163-213.

13. Ergün N. Identity development: narrative identity and intergenerational narrative identity. Current Approaches in Psychiatry. 2020;12(4), 455-475. https://doi.org/10.18863/pgy.676439.

14. Deppoliti D. Exploration how new registered nurses construct professional identity in hospital settings. The Journal of Continuing Education in Nursing. 2008;39(6):255-62. Doi: 10.3928/00220124-20080601-03.

15. Öhlén J, Segesten K. The professional identity of the nurse: concept analysis and development. J Adv Nurs. 1998;28(4):720-727. https://doi.org/10.1046/j.1365-2648.1998.00704.x.

16. Fagermoen MS. Professional identity: values embedded in meaningful nursing practice. J Adv Nurs. 1997;25(3), 434-441. Doi: 10.1046/j.1365-2648.1997.1997025434.x.

17. Spouse J. An impossible dream? Images of nursing held by pre冈registration students and their effect on sustaining motivation to become nurses. J Adv Nurs. 2000;32(3):730-739. https://doi.org/10.1111/j.13652648.2000.01534.x. 
18. Gray M, Smith LN. The professional socialization of diploma of higher education in nursing students (Project 2000): a longitudinal qualitative study. J Adv Nurs. 1999;29(3), 639-647. Doi: 10.1046/j.1365-2648.1999.00932.x.

19. Ryynänen K. Constructing physician's professional identity: Explorations of students' critical experiences in medical education. Oulun yliopisto. 2001;143(1).

20. Shahr HSA, Yazdani S, Afshar L. Professional socialization: an analytical definition. J Med Ethics Hist Med. 2019;12(1):17-30. Doi: https://doi.org/10.18502/jmehm.v12i17.2016.

21. Tanriverdi H, Akova O, Zorlu R. Investigation of the Relationship between Approaches to Nursing Profession and Social Status. Journal of Performance and Quality in Health. 2015;7(1):115-142. https://doi.org/10.37989/ gumussagbil.691612

22. Demir S, Kocaman Yıldırım N. Determination of professional behaviors of psychiatric nurses. J Psy Nurs. 2014;5(1): 25-32. Doi: 10.5505/phd.2014.77487.

23. Dikmen Y, Yönder M, Yorgun S, Usta Y, Umur S, Aytekin A. Examining the professional attitudes of nurses and the factors affecting this. Anatolian Journal of Nursing and Health Sciences. 2014;17(3):25-32.

24. Beydag K, Arslan H. The view of Denizli Health College students about their educations and their professional expectations. Pam Med J. 2008;1(3):137-142.

25. Madsen W, McAllister M, Godden J, Greenhill J, Reed R. Nursing's orphans: How the system of nursing education in Australia is undermining professional identity. Contemporary Nurse. 2009;32(1-2):9-18. Doi: 10.5172/ conu.32.1-2.9.

26. Altıok Öner H, Üstün B. Professionalism: Concept Analysis. DEUHEFED. 2014;7(2):151-155.

27. Gönç T. Professionalization of nursing profession in turkey developments and challenges in the process: a sociological review. Work, power: The Journal of Industrial Relations \& Human Resources. 2015;17(4):113-146. Doi: 10.4026/1303-2860.2015.0301.x.

28. Sabancioğulları S, Doğan S. Professional image and nursing dimension reflected to out of professional identity. HEAD. 2011;8(2):28-38.

29. Erdil F, Başer M, Kaya H, Özer N, Duygulu S, Orgun F. Nursing National Core Education Program. Ankara, Higher Education Council. 2014.

30. Kocaman G, Arslan Yürümezoğlu H. Situation analysis of nursing education in turkey: nursing education by the numbers (1996-2015). J Higher Edu Sci. 2015;5(3):255-262. Doi: 10.5961/jhes.2015.127

31. Tuna R. Instructor and student nurse breeding distribution in higher education institutions in Turkey. JHNM. 2015;2(2):94-99. doi:10.5222/SHYD.2015.094.

32. Presidency of the Republic of Turkey, Legislation Information System. [Internet] 2016 [Retrieved September 21 May 2020]. Access Address: https://www.mevzuat.gov.tr/

33. Aydın Adnan Menderes University Faculty of Nursing, Course Information Forms [Retrieved08.01.2021]. Access Address: https://obisnet.adu.edu.tr/PDFDERSF5?id_OgretimProgram=1369\&id_Ders=20694\&id_ EgitimDil=1\&basicAuthentication $=28330085$

34. Dokuz Eylül University Course Catalogue/ Information Package. [Retrieved08.01.2021]. Access Address: https:// debis.deu.edu.tr/ders-katalog/2015-2016/tr/tr_1229_1229_229.html

35. İzmir Kâtip Çelebi University Faculty of Health Sciences Department of Nursing. [Retrieved08.01.2021]. Access Address: https://sbf.ikcu.edu.tr/Share/DB7342ACB938DD7B904D28FC93D93D84

36. Sivas Cumhuriyet University Faculty of Health Sciences Department of Nursing Undergraduate Program [Retrieved08.01.2021]. Access Address: https://saglikbilimleri.cumhuriyet.edu.tr/webdosya/4167_hemsirelik_ bolumu_ders_icerikleri5c8e045f0444fcaea74514e02ba3886c.pdf

37. Wu C, Palmer MH, Sha K. Professional identity and its influencing factors of first-year post-associate degree baccalaureate nursing students: A cross-sectional study. Nurse education today. 2020;84(1):104227. https://doi. org/10.1016/j.nedt.2019.104227.

38. Bagnasco A, Zanini M, Catania G, Aleo G, Sermeus W, Sasso L. Implications of a wide冈scale educational intervention to engage nurses in evidence冈based practice: The Italian RN4CAST experience. In Nursing forum. 2019;54(2):183-191. https://doi.org/10.1111/nuf.12313. 
39. Kırıkkaleli Z, Şahin N. Nursing education abroad from past to present. JAREN. 2019;5(1):67-72. Doi:10.5222/ jaren.2019.00719

40. Huffman J, Inoue M, Asahara K, Oguro M, Okubo N, Umeda M, Saitoh A. Learning experiences and identity development of Japanese nursing students through study abroad: a qualitative analysis. Int J Med Educ. 2020;11(1):54-61. Doi: 10.5116/ijme.5e47.cf1b

41. Chuan OL, Barnett T. Student, tutor and staff nurse perceptions of the clinical learning environment. NEP. 2012;12(4):192-197. https://doi.org/10.1016/j.nepr.2012.01.003.

42. Sun L, Gao Y, Yang J, Zang XY, Wang YG. The impact of professional identity on role stress in nursing students: A cross-sectional study. IJNS. 2016;63(1):1-8. https://doi.org/10.1016/j.ijnurstu.2016.08.010.

43. Sabancioğulları S, Doğan S. Effects of the professional identity development programme on the professional identity, job satisfaction and burnout levels of nurses: A pilot study. International Journal of Nursing Practice. 2015;21(6):847-857. https://doi.org/10.1111/ijn.12330.

44. Certified Training Programs Conducted by the General Directorate of Public Hospitals, General Directorate of Patient Services and Education Department https://khgmsaglikbakimdb.saglik.gov.tr/TR,34300/genelmudurlugumuz-tarafindan-yurutulen-sertifikali-egitim-programlari.html 